\title{
«НІЧОГО В ЖИТТІ НЕ ЗРІКАЮСЬ» (ЖИТТЄВИЙ ШЛЯХ ТА ІНТЕЛЕКТУАЛЬНА БІОГРАФІЯ ОЛЬГИ ДІДЕНКО)
}

\author{
Сергій Куценко ${ }^{1}$, Ігор Опацький', Наталія Пиж'янова ${ }^{3}$ \\ Уманський державний педагогічний університет імені Павла Тичини (Умань, Україна) \\ 1e-mail: kutsenko.udpu@gmail.com; ORCID: https://orcid.org/0000-0003-0574-786X \\ 2e-mail: igor.opatskiy@gmail.com; ORCID: https://orcid.org/0000-0002-6786-3295 \\ 3e-mail: pyzhianova89@gmail.com; ORCID: https://orcid.org/0000-0001-9347-6566
}

Висвітлено життєвий шлях та інтелектуальну спадщину відомої уманської краєзнавиці, активної діячки пам'яткоохоронного руху другої половини ХХ ст., поетеси та громадської активістки Ольги Петрівни Діденко (1916-2010). Простежено процес формування поглядів О. Діденко, ї̈ найближче інтелектуальне оточення й основні досягнення у дослідженні історії Уманщини. Розглянуто інтелектуальну спадщину О. Діденко: опубліковану та підготовлені, але неопубліковані матеріали з етнографії, історії українського мистецтва та результати багаторічних археологічних експедицій.

Ключові слова: Ольга Діденко, Уманщина, краєзнавство, пам'яткоохоронна діяльність, етнографічні матеріали

У зміцненні національної самосвідомості та відновленні історичної пам'яті непересічне місце належить краєзнавству. Ознайомлення з історією українського краєзнавчого руху, здобутками краєзнавчих організацій та їхніх членів у непростих українських реаліях має особливу значимість. Територія Уманщини, як історикогеографічного регіону, багата на історичні події, які мали вагоме значення для всієї України. Багата історія краю захоплювала багатьох дослідників здійснювати краєзнавчі дослідження й оберігати історичні пам'ятки від руйнування. Після відновлення незалежності України постали біографічні портрети уманських краєзнавців: Григорія Храбана, Надії Суровцової, Петра Курінного, Василя Стефановича. Однак поза належною увагою дослідників залишається постать знаної учасниці краєзнавчого руху, відомої громадської діячки та поетеси Ольги Петрівни Діденко.

Більшість інформації про неї опубліковано на сторінках регіональної преси ${ }^{1}$, або ж зберігається в архівах². Цінним джерелом для дослідження життєпису Ольги Діденко є спогади їі рідних, колег та однодумців, збірку яких було підготовлено уманськими краєзнавцями з нагоди 100-річного ювілею краєзнавиці ${ }^{3}$ Вважаємо за потрібне здійснити спробу систематизації розрізненого біографічного матеріалу про Ольгу Діденко, а також означити інтелектуальну спадщину дослідниці.

Народилася Ольга Петрівна Діденко 18 липня 1916 р. на Івангородському передмісті Умані. Родина Діденків вважалася, за словами О. Діденко, середніх достатків. Батько Петро Никифорович Діденко володів 8 десятинами землі, кіньми та сільсько-

\footnotetext{
13 днем народження, людино! // Уманська зоря. 2005. 23 липня. С. 3; Касумова Р. Українська горлиця // Уманська зоря. 2007. 8 серпня. С. 2.; Ляшенко О. Її щирий дар // Уманська зоря. 1997. 8 березня. С. 2.

2 Державний архів Черкаської області (ДАЧО) Ф. Р-5586. Оп. 1. Спр. 10; Фонди Уманського краєзнавчого музею.

3 Скуратівська О. та ін. Україна Ольги Діденко. Київ: Талком, 2017. 134 с.
} 
господарським реманентом. У шлюбі з Гафією Данилівною Гончаренко у них народилося семеро дітей. 3 початком політики колективізації батьки вступили в артіль, а старші брати поїхали на заробітки.

Після закінчення семи класів шкільного навчання Ольга Діденко планувала навчатися на трактористку, однак її родину більшовицька влада зарахувала до категорії неблагонадійних «підкуркульників», у зв'язку з чим дівчину не було прийнято на курси трактористів. У той час в радянській пресі поширювалися повідомлення про спроби «розкуркулених глитаїв» пробратися до ремонтних майстерень машиннотранспортних станцій, до лав трактористів з метою проведення шкідницької роботи. Ймовірно, у зв'язку з цим, О. Діденко було відмовлено у навчанні4. Однак невдовзі вона поступила на педагогічні курси, по закінченню яких у 1933-1934 рр. працювала у селі Велика Севастьянівка Христинівського району на Черкащині, а у 1934 р. вступила на мовно-літературний факультет Уманського учительського інституту. 1935 р. два курси мовно-літературного факультету було переведено до Миколаївського державного педагогічного інституту, після закінчення якого О. Діденко виїхала працювати на Донеччину. Після відновлення незалежності України вона пояснювала свій вибір робочого місця тим, що в час розгулу комуністичного терору вона намагалася загубитися у гущі людей, де б вона була не під таким пильним оком радянських спецслужб5.

Працюючи у сільських школах Донбасу, Ольга Діденко познайомилася з випускником Київського університету, вчителем математики Василем Скуратівським, 3 яким невдовзі взяла шлюб. У 1938 р. подружжя переїздить проживати до батьків Ольги Діденко в Умань, де у них народився син Віталій, а через рік - Олександр. Невдовзі після початку Другої світової війни Василя Скуратівського було мобілізовано до армії, а влітку 1941 р. він загинув у районі села Підвисике (нині Новоархангельського району Кіровоградської області) в урочищі Зелена Брама. Ольга Діденко впродовж 1941-1944 рр., разом з сестрою Ніною Діденко, була активною учасницею підпільної антигітлерівської групи студента Уманського державного учительського інституту Андрія Романщака. Ця група співпрацювала з усіма, хто боровся проти німецької окупаційної влади, у тому числі з Організацією Українських Націоналістів. Під час війни Ольга Діденко допомагала втікачам з табору «Уманська яма», а також виготовляла фальшиві посвідчення та документи, які допомагали місцевій молоді уникнути вивезення на примусові роботи до Німеччини. Ольга Петрівна друкувала на друкарській машинці бланки українською та німецькими мовами, до яких вписувала потрібні дані про людинуб.

Варто зазначити, що рятуючи молодь під час війни, Ольга Діденко співпрацювала з представниками різних ідеологічних груп: перебувала у складі комсомольської групи Андрія Романщака, папером для виготовлення бланків «аусвайсів» їі забезпечували працівники Уманського куща поліції Андрієтті та Тимощенко, а автором печатки для завірення підроблених документів був член ОУНівського підпілля, талановитий гравер Матвій Сухина. У 1941 р. Ольга Діденко виготовила кількасот фальшивих документів для лісничого з Маньківського району на прізвище Стеценко,

\footnotetext{
${ }^{4}$ Ibid. C. 14.

5 Смілянець Л., Пашковський О. Жити - значить боротись (життєпис Ольги Петрівни Діденко) // Краєзнавство Черкащини. 2011. № 9. С. 173.

6 Треба слово сказати, заповітне, єдине...: поезії, спогади, світлини, автографи / Упорядник П. Ямчук. Умань: Видавничо-поліграфічний центр «Візаві», 2017. С. 16.
} 
який був членом ОУНівського підпілля. Згадуючи про ті часи, О. Діденко з гордістю заперечувала, що виготовляла фіктивні документи: «Ну чому фальшиві? У мене всі аусвайси були справжні - з німецькою печаткою. Все як має бути!». Загалом, кожного разу піддаючи ризику себе та своїх дітей, О. Діденко виготовила понад 300 посвідчень ${ }^{7}$.

Після відновлення у березні 1944 р. в Умані радянської влади, Ольга Діденко прийняла рішення залишити Уманщину та поїхати вчителювати на Прикарпаття. Можемо здогадуватися, що таке рішення було прийнято з метою уникнути викриття радянськими спецслужбами фактів співпраці з націоналістичним підпіллям. Вчителюючи на Прикарпатті, активно займалася пошуковою та дослідницькою роботою, збирала усну народну творчість для Інституту фольклористики АНУРСР, 1949 р. була учасницею семінару з питань народної поезії, організованому Всесоюзним Будинком народної творчості у Москві8.

1960 р. у зв'язку з хворобою матері, яка вже не могла належним чином піклуватися про синів Ольги Віталія та Олександра, вона повертається до Умані. Перший час працювала вчителькою у с. Антонівка Уманського району, однак невдовзі залишає вчителювання та розпочинає працювати екскурсоводом, науковим співробітником в Уманському краєзнавчому музеї. У музеї на той час працювали відомі краєзнавці Григорій Храбан і Василь Стефанович. Ольга Петрівна з головою поринає в пам'яткоохоронну справу та краєзнавчу роботу, збирає та записує народні пісні, кахлі, кераміку, наличники та кургани, історію «Софіївки», дослідження Руху опору на Уманщині у 19411945 рр. Загалом за час роботи в музеї О. Діденко розробила експозицію, присвячену Другій світовій війні, збирала спогади учасників війни та їі свідків.

Активно Ольга Діденко займалася археологічними дослідженнями, досліджувала археологічні пам'ятки Уманщини різних історичних епох, зокрема, поселення Трипільської археологічної культури та кургани ${ }^{9}$. 31963 р. за пропозицією В. Стефановича приєднується до роботи над збірником «Археологічні пам'ятки Уманщини». Потреба у такому збірнику була зумовлена тим, що під час паспортизації археологічних пам'яток до офіційного реєстру було внесено лише 60 пам'яток з території історичної Уманщини (територія середньої течії річки Південний Буг, сучасні Уманський, Катеринопільський, Жашківський, Звенигородський, Маньківський, Монастирищенський, Маньківський, Тальнівський, Христинівський, Теплицький i, частково, Ново-Архангельський та Голованівський райони). Це викликало обурення місцевих краєзнавців, у першу чергу, В. Стефановича, який ще з 1954 р. розпочав роботу над формуванням збірника. В одному з листів до Ольги Петрівни Василь Стефанович зазначав: «А що буде далі? Хто буде продовжувати справи вивчення археологічних пам'ятників (тоді, коли вони на очах нищаться. Вам відомо, значна частина їх вже загинула). Чи можна погодитися, що ця робота припиниться? Нi, це не може бути. Робота ця повинна продовжуватися... О. П., мені здається, що ця «естафета» повинна бути передана Вам і тільки Вам»10.

Спільними зусиллями В. Стефановича та О. Діденко було зібрано великий масив доступної інформації про археологічні знахідки на території Уманщини до 1968 р.

\footnotetext{
7 Смілянець Л., Пашковський О. Вказ. пр. С. 174.

8 Касумова Р. Українська горлиця // Уманська зоря. 2007. 8 серпня. С. 2.

9 Відейко М. Діденко Ольга Петрівна // Енциклопедія Трипільської цивілізації. Київ, 2004. Т. 2. C. 149.

10 ДАЧО. Ф. Р-5586. Оп. 1. Спр. 10. Арк. 22.
} 
Авторами представлено інформацію про обставини виявлення знахідок, назви предметів і знарядь, а також про те, де і в яких умовах вони зберігалися у 1968 р. При укладанні збірника автори використали доступні на той час матеріали археологічних досліджень, наукову літературу, матеріали зі щоденників і звітів керівників археологічних експедицій (зокрема, згадували й за відкриття табуйованого «ворога народу» Петра Курінного).

В. Стефанович у передмові до збірника висловлював сподівання, що з часом «Збірник...» стане колективною працею співробітників Уманського краєзнавчого музею, який, «як естафета, послідовно передаватиметься для поповнення від одного наукового співробітника до іншого»11.

3 метою оминути заборону цензури на публікацію дослідження, автори написали його російською мовою й отримали позитивний відгук відомого археолога Д. Телегіна, який серед іншого зазначив: «Книга содержит в большинстве своем оригинальные сведения, о которых здесь говорится впервые и поэтому она является важным первоисточником по археологии Черкащины... Хотелось бы иметь подобные сборники по археологии во всех музеях Украины»12. Однак після закінчення підготовки до друку «Збірника...» обставини склалися так, що результат багаторічної копіткої праці автори були змушені випустити у світ методом «самвидаву» в кількості 50 примірників, які були розповсюджені серед шанувальників історії рідного краю, а кілька примірників передано на зберігання у фонди Уманського та Черкаського музеїв, бібліотеку Інституту археології АН УРСР.

3 ініціативи Н. Суровцової та на прохання правління Всеукраїнського товариства охорони пам'яток історії та культури при Уманському музеї було створено ініціативну групу з охорони пам'яток культури та архітектури. Цю групу очолила Ольга Діденко. За допомогою аматорів старовини, краєзнавців, школярів і просто небайдужих людей, члени ініціативної групи розшукували та здавали на довічне зберігання Уманському краєзнавчому музею різні старовинні речі. Завдячуючи копіткій праці О. Діденко фонди Уманського краєзнавчого музею поповнилися сотнями експонатів 13 .

Спільно з В.Стефановичем О.Діденко проводила археологічні дослідження під час здійснення реконструкції міста та зведення новобудов. Ними було виявлено добре збережену стратиграфію культурних шарів, людські скелети, уламки посуду XVIII ст., землянки, фрагменти гончарних виробів, уламки кахлів із зображенням вершника на коні та низку інших знахідок. До речі, товариські взаємини О. Діденко 3 В. Стефановичем тривали і після переїзду Василя Автономовича до черкаського будинку-інтернату для престарілих. Окрім глибокої взаємоповаги їх об'єднували ще й спільні цінності - дослідження та збереження історичної спадщини. Зі збереженого листування відомо, що В.Стефанович високо цінував пам'яткоохоронну діяльність своєї колеги, називав її «маяком в Арктиці» та запрошував на відзначення 95-ти літнього ювілею.

У 1968 р. Ольга Діденко працювала над перебудовою музейної експозиції, присвяченої 200-літтю подій Гайдамаччини. 1969 р. працювала над створенням Жашківського районного краєзнавчого музею, запропонувала власну концепцію мережі музейних кімнат і куточків. Збираючи етнографічну інформацію вона пішки обійш-

\footnotetext{
11 Діденко О., Стефанович В., Чорномаз Б. Збірник археологічних пам'яток Уманщини. Умань, 2006. С. 28.

12 Стефанович В., Діденко О. Археологічні пам'ятки Уманщини: У 2-х тт. Т. 2. Умань, 1968. С. 2.

13 Скуратівська О. та ін. Україна Ольги Діденко... С. 88.
} 
ла майже всю Уманщину, спілкувалася зі старожилами та записувала від них народні пісні, перекази, а також топографічні назви. Досліджувала на Уманщині старі сільські хати з дерев'яними наличниками, фотографувала та замальовувала їх, збирала фрагменти старовинних кахлів і замальовувала з них візерунки. Планувала створити у краєзнавчому музеї етнографічну кімнату присвячену тематиці віконного різьблення та стінного розпису хат. Завдячуючи їі зусиллям вдалося зафіксувати близько 100 оригінальних зразків різьблення, зробити альбом фотографій і малюнків, опублікувати кілька газетних публікацій. У 1985 р., коли О. Діденко зробила повторний огляд досліджених нею об'єктів, то з'ясувалося, що половина з них вже зникли. Збірку матеріалів про наличники Уманщини О.Діденко готувала тривалий час, однак вже у роки незалежності України ії помешкання двічі грабували. Одного разу, окрім побутових речей, злочинці вкрали частину їі рукописів, які не віднайдені і до сьогодні 14.

Найбільшим своїм науковим досягненням О.Діденко вважала розшифрування географічних назв Уманщини на картах Гійома Левасера де Боплана. Складність при розшифруванні полягала у тому, що автор-іноземець писав свої твори на нормандському діалекті старої французької мови, для картографування вживав латину, на території України перебував у польському оточенні від якого переважно і брав інформацію. Ольга Петрівна, проаналізувавши назви географічних об’єктів, дійшла висновків, що Боплан уникав вживання літери Щ, погано розрізняв Г, К, Х і Ж, Ч, Ш (для прикладу поселення Кочубіївка було записано як Косовіовка). Автором було розшифровано нанесені Бопланом назви об'єктів території Уманщини та подано їх сучасні назви ${ }^{15}$.

Працюючи у музеї, Ольга Діденко познайомилася з відомою особистістю - Надією Суровцовою, навколо якої сформувався гурт національно свідомої інтелігенції «уманський салон», що був одним із центрів шестидесятницького руху. Р. Корогородський зазначав, що завдячуючи Н. Суровцовій «Умань перетворилася на Мекку - туди їздили «батьки і діти» українського Відродження»16. До кола відвідувачів будинку Н. Суровцової входила й О. Діденко. Надія Суровцова пройнялася щирою турботою за долю краєзнавиці, цінувала її вірші та допомагала з першими публікаціями. Леонід Первомайський у листах до Н. Суровцової позитивно відгукувався про творчість О. Діденко. Зокрема, у листі від 20 вересня 1961 р. він зазначав: «ерекажіть Вашій приятельці, що я схиляюсь перед тим стражданням їі, що змогло породити таку сильну і потрібну людській душі поезію... Дозволяю собі просити Вас передати Вашій приятельці мою книжку, яку шлю разом 3 цим листом»17. Поезї О. Діденко зацікавили й Миколу Бажана, який згодився написати передмову до їі першої збірки, а це було значне досягнення, яким поетеса завдячувала i Н. Суровцовій. У 1962 р. вірші уманської поетеси були опубліковані у літературній газеті та журналі «Вітчизна».

У багатьох листах Л. Первомайського до Н. Суровцової йшлося і про О. Діденко. Виписані цитати з цих листів збереглися серед паперів Ольги Петрівни: «Радий дуже за Ольгу Петрівну - її вірші тут добре прийняли. Коли б і вона сама доклала зусиль, більше писала і надсилала до редакцій, можна було б думати і про першу книжку», а

\footnotetext{
${ }^{14}$ Смілянець Л., Пашковський О. Вказ. пр. С. 176.

15 Діденко О. Уманьщина на картах Г. Боплана // Історико-географічні дослідження в Україні. 1988. С. 84-89.

16 Корогородський Р. Природа доброти й сподівання // Кур'єр Кривбасу. 1997. № 77-78. С. 136.

17 Скуратівська О. та ін. Україна Ольги Діденко... С. 30.
} 
в іншому листі він інформував: «...а ще є такі особи, що навмисне не друкують те, що я рекомендую, хоч і самі бачать, що воно добре... От хоч би той Дмитренко - прочитав у вірші Ольги Петрівни рядок: «Скажи мерзоті: ти мерзота», почервонів як буряковий квас і дав зрозуміти, що він цього не надрукує... До речі - пише вона тепер і що пише? Шкода, коли покинула, з неї був би поет і неабиякий...» (лист від 1969 р.). Високо цінував поетичний талант О. Діденко і академік Костянтин Ямчук, який характеризував її словами «Гениальный украинский поэт. Уникально порядочный человек»18.

Завдячуючи дружбі з Н. Суровцовою, О. Діденко познайомилася з багатьма представниками української інтелігенції (до Умані приїздили Галина Дидик, Дарина Гусяк, Юрій Смолич, Микола Бажан, Павло Тичина, Надія Мудра, Олена Степанів, Михайлина Коцюбинська, родина Світличних, Лариса Скорик, Олександр Солженіцин, Леонід Плющ, Іван Драч та ін.), а особисті взаємини двох жінок були просякнуті повагою й турботою. Однак О. Діденко згадувала, що «Суровцова ніколи не змішувала людей». Одного разу, коли Ольга Петрівна прийшла до Надії Віталіївни по роботі, господиня порадила їй навідатися трішки пізніше, бо у неї відвідувачі, з котрими О. Діденко не варто зустрічатися. Н. Суровцова, яка приймала у себе на квартирі діячів ОУН-УПА, українських і російських дисидентів розуміла, що зустрічі з окремими $з$ них можуть стати причиною додаткової уваги радянських спецслужб до О. Діденко. Вірш Ольги Петрівни «На іменини» (1964р.), присвячений Н. Суровцовій, містить такі рядки: «Люди плачуть за роками./ От чи вірите, чи ні,/ Як милуюсь нишком Вами,/ Заздрю Вашій сивині»19.

Наприкінці 1960-х рр. у помешканні Ольги Діденко на вулиці Мирводи, 23 було організовано уманський пункт виготовлення «самвидаву». Богдан Чорномаз, Кузьма Матвіюк, Ольга Діденко та їі син Віталій Скуратівський дістали фотоапаратуру та різне начиння для масового виготовлення фотокопій. Надруковані у помешканні О. Діденко фотокопії з текстом праці Івана Дзюби «Інтернаціоналізм чи русифікація?» поширювалися в Умані, Тернополі, Чернівцях, Києві. 13 липня 1972 р. Б. Чорномаза та К. Матвіюка було заарештовано. Слідство тривало півроку, однак під час нього арештантам вдалося зберегти у таємниці місце розташування пункту розмноження «самвидаву» та не обмовитися про причетність до цих подій О. Діденко та іï сина. Б. Чорномазу та К. Матвіюку було присуджено терміни ув'язнення: три та 4 роки таборів суворого режиму в статусі «особливо небезпечний державний злочинець» ${ }^{20}$.

Після звільнення з Уманського краєзнавчого музею за сфабрикованим доносом 3 1974 по 1988 рік співпрацювала з Черкаським обласним музеєм на громадських засадах, з 1989 по 1993 рік працювала у цьому ж музеї як штатний співробітник, з 1993 по 2001 рр. - науковий співробітник Черкаської обласної археологічної експедиції, готувала матеріали до «Зводу пам’яток історії та культури», здійснювала археологічні розвідки у західних районах Черкаської обл. 1987-1988 рр. О. Діденко стала одним із засновників і лідерів культурологічного товариства «Берегиня». Напрямами роботи товариства було визначено: обстеження курганів, відновлення народних обрядів і звичаїв, популяризацію народної пісенної творчості, збереження Грекового лісу як історичної пам'ятки, передача відібраних у віруючих храмів громадам, пору-

\footnotetext{
18 Треба слово сказати, заповітне, єдине... С. 19.

19 Ibid. C. 109.

20 Записано зі спогадів Богдана Чорномаза.
} 
шення питання про встановлення в Умані пам'ятника лідерам гайдамацького руху Максиму Залізняку та Івану Гонті, збереження природнього середовища тощо21.

В архіві Тетяни Чорномаз зберігся звіт товариства за 1989 р., де зазначено пророблену роботу: «обстежено курганів в селі Красноставка Маньківського району, обстеження в селі Молодецьке стародавнього поселення II-VIII ст. до н.е., обстеження курганного могильника в с.Нестерівка, в с.Гереженівка виявлено історичну пам'ятку «Гродзьонний Яр», проведено обстеження городища міста Умані при розкопках на будівництві Критого ринку».

Часто під час археологічних або етнографічних експедицій Уманщиною О. Діденко доводилося ночувати у випадкових людей, в яких вона цікавилася інформацією про життя села, його історію та звичаї. Ольга Діденко не лише збирала народні пісні, вона ще й відтворювала їх і популяризувала. Під ії керівництвом члени товариства «Берегиня» організували у міському Будинку культури за участі школярів і студентів вечір колядок і щедрівок, влітку було відтворено Купальський обряд. Частина записаних Ольгою Діденко колядок і щедрівок з території історичної Уманщини увійшли до репертуару аматорського етнографічного хору «Гомін» під керівництвом Леопольда Ященка. Ще один напрям діяльності товариства - розслідування походження братських могил на Міщанському кладовищі, де влітку 1989 р. члени товариства розчистили могили жертв комуністичних репресій від чагарників.

За визначний вклад в історичні та краєзнавчі дослідження, збереження та популяризацію історичних пам'яток у 1992 р. Черкаське обласне управління Товариства охорони пам'яток історії та культури вручило Ользі Діденко премію імені Василя Стефановича. 23 грудня 1997 р. її було нагороджено премією імені Вікентія Хвойки за охорону пам'яток археології Всеукраїнським товариством охорони пам'яток історії та культури. У цьому ж році вийшла перша збірка їі віршів «І у горі завжди зоря була...». 6 березня 2001 р. Уманською міською владою Ольгу Петрівну було визнано «Жінкою року - 2000» в номінації «Жінка-митець». 21 травня 2010 р. Ольга Петрівна Діденко пішла у засвіти, залишивши понад дві сотні наукових праць, більша частина з яких ще чекає своїх дослідників.

Таким чином аналіз життєвого шляху й інтелектуальної праці Ольги Діденко дозволяє дійти висновків, що своїм життям вона прислужилася справі збереження та вивчення української культурної спадщини. Завдячуючи консолідованій праці О. Діденко з Н. Суровцовою, В.Стефановичем, членами товариства «Берегиня» було записано велику кількість етнографічного матеріалу, а фонди Уманського краєзнавчого музею поповнилися тисячами цінних експонатів, які $\epsilon$ цінним джерелом для дослідження історії краю.

\section{REFERENCES}

Didenko, 0. (1988). Umanshchyna na kartakh H. Boplana [Umanschina on the maps of G. Boplan]. Istoryko-heohrafichni doslidzhennia v Ukraini, 84-89 [in Ukrainian].

Didenko, O., Stefanovych, V. \& Chornomaz, B. (2006). Zbirnyk arkheolohichnykh pamiatok Umanshchyny [Collection of archeological monuments of Uman region]. Uman [in Ukrainian].

Kasumova, R. (2017). Ukrainska horlytsia [Ukrainian throat]. Umanska zoria, August 8, 2 [in Ukrainian].

Korohorodskyi, R. (1997). Pryroda dobroty y spodivannia [The nature of kindness and hope]. Kurier Kryvbasu, 77-78, 135-143 [in Ukrainian].

Liashenko, 0. (1997). Yii shchyryi dar [Her sincere gift]. Umanska zoria, March 8, 2 [in Ukrainian].

Skurativska, 0. (2017). Ukraina Olhy Didenko [Ukraine of Olha Didenko]. Kyiv: Talkom [in Ukrainian].

21 Скуратівська О. та ін. Україна Ольги Діденко... С. 59. 
Smilianets, l. \& Pashkovskyi, 0. (2011). Zhyty - znachyt borotys (zhyttiepys Olhy Petrivny Didenko) [To live means to fight (Olga Didenko's biography)]. Kraieznavstvo Cherkashchyny, 9, 173-178 [in Ukrainian].

Stefanovych, V. \& Didenko, 0. (1968). Arkheolohichni pamiatky Umanshchyny [Archeological monuments of the Uman Region]. Uman [in Ukrainian].

Videiko, M. (2004). Didenko Olga Petrivna [Didenko Olga Petrivna]. Entsyklopediia Trypilskoi tsyvilizatsii, Vol. 2. Kyiv [in Ukrainian].

Yamchuk, P. (Ed.) (2017). Treba slovo skazaty, zapovitne, yedyne...: poezii, spohady, svitlyny, avtohrafy [The word must be said, treasured, one thing...: poetry, memories, photos, autographs]. Uman: Vizavi [in Ukrainian].

\section{Serhii Kutsenko}

(Pavlo Tychyna Uman State Pedagogical University, Uman, Ukraine)

ORCID: https://orcid.org/0000-0003-0574-786X

\section{Igor Opatskiy}

(Pavlo Tychyna Uman State Pedagogical University, Uman, Ukraine)

ORCID: https://orcid.org/0000-0002-6786-3295

\section{Nataliia Pyzhianova}

(Pavlo Tychyna Uman State Pedagogical University, Uman, Ukraine)

ORCID: https://orcid.org/0000-0001-9347-6566

\section{«I Don't Renounce Anything in My Life» (Olha Didenko's Life Path and Intellectual Biography)}

The paper deals with the life path and intellectual heritage of well-known Uman local lore specialist, an activist of the monuments protection movement of the second half of the $20^{\text {th }}$ century, the poetess and public activist Olha Petrivna Didenko. The main milestones of her biography are reproduced on the basis of the memories of people who knew O. Didenko personally and collaborated with her. It is noted that deep self-education and communication with like-minded people had a significant influence on the formation of her patriotic views. The circle of the closest intellectual environment of 0 . Didenko included well-known figures of Ukrainian movement: Nadiia Surovtsova, Vasyl Stefanovych, Mykhailo Braichevskyi, Leonid Pervomaiskyi, Mykola Bazhan.

The effective cooperation of O. Didenko with N.Surovtsova and V. Stefanovych had significant results: the funds of the Uman Regional Museum were broadened with thousands of new items, a large number of ethnographic materials were recorded and certain archaeological researches were conducted. Many years of study resulted in the «Collection of Archaeological Monuments of Uman Region» prepared for publishing. This collection contains information about the archaeological findings found on the territory of the villages of the historical Uman region, their characteristics and the state of their preservation.

A separate area of Olha Didenko's work was monuments protection. She studied mounds and archeological sites on the territory of the historical Uman region, addressed letters to the city and regional authorities demanding to prevent the destruction of the monuments. Very important for the local lore history of the Uman region is the study of geographical names on the maps of Beauplan performed by Olha Didenko. She managed to transcribe the names from the map and correlate them with the modern names of the settlements. For a long period of time, O. Didenko studied window carvings in Uman region, took pictures and copied them.

0 . Didenko was also engaged in the social life of the region. During the «perestroika» policy, she became one of the initiators of «Beregynia» cultural society establishing in Uman. The members of this society were engaged in the study of the historical past, monuments protection activity and the revival of Ukrainian national traditions. Under the leadership of 
O. Didenko, the events were held in the city to celebrate Christmas, Ivan Kupala and other holidays of the calendar-ritual cycle.

Keywords: Olha Didenko, Uman region, local lore, monuments protection activity, ethnographic materials 